ANUARIO DE ESTUDIOS MEDIEVALES 42/2, julio-diciembre de 2012, pp. 727-753

ISSN 0066-5061

doi:10.3989/aem.2012.42.2.15

\title{
REPRESENTATIVIDAD POLÍTICA Y REBELIÓN URBANA A FINES DEL MEDIEVO: LAS ASAMBLEAS DEL COMÚN TOLEDANO (1478-1522) ${ }^{1}$
}

\author{
POLITICAL REPRESENTATION AND URBAN REVOLT \\ AT THE END OF THE MIDDLE AGES: \\ THE ASSEMBLIES OF THE COMÚN IN TOLEDO (1478-1522)
}

\begin{abstract}
Resumen: Aunque la acción conjunta de las oligarquías locales y la realeza consiguió marginar del gobierno a la población urbana, en muchas ciudades no desapareció la voluntad del común de intervenir en los asuntos públicos, para lo que empleó todos los mecanismos a su alcance (habitualmente de naturaleza pacífica, pero a menudo también de carácter violento). En Toledo la participación en las juntas de las parroquias que se celebraban para nombrar a los jurados eran el único sistema de acción política que le quedaba al común en el siglo XV, y, aun así, tenía que sufrir toda clase de abusos por parte de los poderosos; unos abusos que se aceptaban con resignación, pero que degradarían la imagen del Cabildo de jurados, representante de los pecheros en la urbe, hasta situarlo en el punto de mira de la furia popular en sublevaciones como las de 1449 y 1467 , y sobre todo en 1520 .
\end{abstract}

Palabras clave: pecheros; cabildo de jurados; representación política; comunidades de Castilla; parroquias; clientelismo; diputados.

\begin{abstract}
Although the joint action of local elite and royalty managed to marginalize the urban population from government, in many cities the desire of pecheros to participate in public affairs did not disappear, for they used every means available -usually peaceful, but occasionally of a violent nature. In Toledo the only remaining system of political action of the común in the XV century was the participation in parish meetings to appoint juries, yet despite this, the pecheros suffered all kinds of abuse by the powerful; abuses accepted with resignation, but which degraded the image of the Cabildo de jurados, representing the comun in the city, making it the focus of popular rage in the uprisings of 1449, 1467 and especially between 1520 and 1522.
\end{abstract}

Keywords: commoners; council juries; political representation; communities of Castile; parish; clientelism; deputies.

\footnotetext{
${ }^{1}$ Abreviaturas utilizadas: ACJ = Archivo del Cabildo de Jurados; AGS = Archivo General de Simancas; $\mathrm{AMT}=$ Archivo Municipal de Toledo; $\mathrm{BNM}=$ Biblioteca Nacional de Madrid; $\mathrm{CC}=$ Cámara de Castilla; $\mathrm{DO}=$ Documentos Originales; doc. = documento; leg. = legajo; ms. = manuscrito; RGS $=$ Registro General del Sello.

El presente trabajo se ha realizado en el marco del proyecto: "Impacto urbano, actividad productiva y sociabilidad en las villas y ciudades castellanas del eje económico Toledo-Burgos (14501520)" del MICINN, HAR2010-15422.
} 


\section{SUMARIO}

1. Introducción.- 2. Las asambleas de parroquianos en la paz. Análisis a partir de la documentación toledana de fines del siglo XV.- 3. Una evolución en las formas de la representatividad popular. Las juntas de la Congregación en época de las Comunidades.- 4. A modo de conclusión.- 5. Bibliografía citada.

\section{INTRODUCCIÓN}

En el siglo XV la literatura supo hacerse eco de las frustraciones políticas y sociales que atormentaban al pueblo llano, al común, aunque por lo general los prosistas, anónimos o no, no pasaban del lamento. Muy pocas veces se advertía sobre lo peligroso de desatender a los humildes, quienes no teniendo un poderío de facto sí ostentaban una fuerza como grupo que no podía menospreciarse, y que en la literatura se solía legitimar o bien con apelaciones a la providencia divina o bien, con una cosmovisión más furibunda, recurriendo a ideas en torno a la defensa a ultranza del bien común, si fuese necesario mediante la violencia². El Libro de los enxemplos es paradigmático, en este sentido. En muchas ocasiones sus argumentos son de una radicalidad adusta: cossa propia e rrazonable es que los menores se levanten a los mayores -se nos dice en sus páginas- (...) a veces van los que son en este mundo menores delante de los mayores (...) los menores dexan vevir a los mayores más por miedo que non por amor. De alguna forma, esta referencia literaria se hace eco de lo que la historiografía medieval define como el "discurso pechero", según algunos autores caracterizado por oponerse sin rubor a las ideas de los omes poderosos en lo relativo al papel de la violencia, las actitudes ante el rey, el régimen tributario, la cultura política, las relaciones sociales, el papel de la justicia, el aprovechamiento de los recursos públicos y, en fin, la cosmovisión más básica ${ }^{3}$. La forma de ver la vida y de percibir el entorno era diferente en función del estatus, dependiendo de si se observaba la realidad "de abajo hacia arriba", caso del común de los pecheros, o "de arriba hacia abajo", como el estado de los caballeros e hidalgos, o lo que es lo mismo, de los omes poderosos. Aun así, en la mayoría de las ciudades existían grupos intermedios, cuya importancia sería primordial en los cambios sociales, políticos y económicos del último cuarto del siglo XV y a comienzos del XVI, que serán los protagonistas de este estudio, y que se caracterizaban por su descolocación social, por estar a caballo entre dos grupos sociales que la historiografía castellana sitúa como antagónicos: los privilegiados y los pecheros-no privilegiados. A ese grupo, actor principal en muchos de los conflictos que se produjeron en las ciudades castellanas en el otoño de la Edad Media, se le han dado diversas denominaciones -desde las más osadas, "preburguesía", "protoburguesía", "naciente burguesía", a las más cautelosas, y en mi opinión oportunas, "élite pe-

\footnotetext{
${ }^{2}$ Cuando más se dejó notar esta furia fue durante la rebelión de las Comunidades. Véase: F. Martínez, Furia popular, pp. 309-364. Con respecto a la legitimación del poder de los humildes mediante la providencia divina, las palabras del Libro de los sabios son claras: "Non despreçies el consejo de los synples, e sobre grand cosa o a que se requiere juyzio, ayunta a los grandes e a los pequeños e ternás en qué escoger. Que muchas vezes enbía Dios su graçia en personas que non se podría pensar, e los consejos son graçia de Dios e non leys escriptas. Aunque el fundamiento de cada cosa sea buena razón, tan aýna e más es dotada a los synples como a los letrados, a los chicos como a los grandes poderosos. E reçibe todos los dichos de los que venieren a ty, que mientra más echan en el saco más aýna se finche", J.K. Walsh, El libro de los doce sabios, cap. XXXVI, p. 107.

${ }^{3} \mathrm{El}$ autor que en los últimos tiempos se ha mostrado más partidario de esta postura es J.M. Monsalvo, como evidencia su estudio Ideario sociopolítico. Estas mismas ideas ya las defendió en un artículo publicado años antes: Aspectos de las culturas políticas.
} 
chera", "segunda oligarquía", "élite del común”-, si bien lo que le caracterizaba era su contradicción interna, en la medida en que, aun proviniendo de las clases populares, del sector pechero, de aquellos a los que la literatura de la época llamaba los menores e medianos, por su posición política poco a poco iría desvinculándose de sus orígenes sociales para acabar convirtiéndose en un grupo de potentados ${ }^{4}$.

El común, o si se quiere el pueblo llano, se caracterizaba por unos factores demográficos (era la mayoría social), políticos (había sido alejado de las instituciones públicas de decisión), económicos (vivía de su trabajo y lo formaban pecheros casi en su totalidad), jurídicos (no gozaba de privilegios, a no ser los establecidos para toda la comunidad) y culturales (albergaba una cosmovisión propia) que le distinguían de los poderosos, las élites o, en términos políticos, los oligarcas. El común de los pecheros se definía por su oposición a la élite privilegiada, aunque su rasgo más ostensible era su carácter heterogéneo, fruto de una compleja articulación social ${ }^{5}$. No en vano, las múltiples situaciones que en él se contenían es lo que hacen difícil el estudio del común, o, para ser precisos, el estudio de los comunes. En este trabajo, sin entrar en cuestiones teóricas que excederían sus fines, se empleará el concepto común globalmente, como sinónimo de pueblo llano, aunque con las debidas puntualizaciones.

\section{LAS ASAMBLEAS DE PARROQUIANOS EN LA PAZ.}

\section{ANÁLISIS A PARTIR DE LA DOCUMENTACIÓN TOLEDANA DE FINES DEL SIGLO XV}

A día de hoy cada vez son más las investigaciones que hablan de la población humilde, con el fin de dar luz a temáticas en las que hace apenas tres décadas la penumbra era insondable ${ }^{6}$. En la actualidad son múltiples las monografías de historia de los grandes núcleos de población que presentan un capítulo dedicado a los menores, en el que se les suele definir como sujetos activos -si bien manipulados y dependientes- en las relaciones de poder de los poderosos. Con cada nueva aportación se conoce más sobre su forma de vida -cómo eran sus viviendas, cómo se vestían, qué comían, cuánto cobraban por su trabajo-, sobre sus dificultades y ambiciones, sobre sus formas de diversión y sobre el éxito o el fracaso de sus iniciativas. Aunque dispersos por un sinnúmero de obras, artículos y recensiones, los datos que tenemos actualmente para reconstruir cómo vivían los menores y los medianos en el siglo XV son profusos, si bien aún se echa en falta un estudio global.

En el presente trabajo, y con el fin de ahondar en el conocimiento de las formas de vida del común, realizaremos un análisis del papel gubernativo de la población pechera de una urbe relevante, como lo era la Toledo de los últimos años del siglo XV y comienzos del XVI. Por entonces, las herramientas de la gente de a pie para intervenir en el sistema político de su ciudad eran escasas, sobre todo de tratarse de un núcleo urbano como el que examinaremos, que aun sin una población excesiva (de unas 25.000 personas) presentaba unas peculiaridades propias, entre las que se tendría que destacar una: la casi total marginación política del común. Al contrario que en

\footnotetext{
${ }^{4}$ Estas contradicciones "de clase" han sido bien estudiadas por J.A. Jara a partir del caso de Cuenca: Doble representación y cruce de intereses, y Posiciones de clase y sistemas de poder.

${ }^{5}$ Véase: M. Asenjo, El pueblo urbano.

${ }^{6}$ Algunas de las aportaciones monográficas más interesantes serían estas: M.J. Parejo, Grupos urbanos no privilegiados; M. Diago, El “común de los pecheros” de Soria; J.M. Monsalvo, La sociedad política, pp. 357- 413; M.I. del Val, Ascenso social; M. Asenjo, Sociedad y vida política; M.A. Martín, Nuevas perspectivas.
} 
ciudades como Cuenca, Segovia, Cuéllar, Mérida, Sepúlveda e incluso Burgos ${ }^{7}$, en las que los pecheros lograron mantener oficios en el Regimiento cerrado, desde los que operarían con fines que no siempre eran los de la "élite de poder", cuando en Toledo se cerró el Regimiento (particularmente tarde, en 1422) el común fue marginado ${ }^{8}$, aunque el rey Juan II, en compensación, creó un Cabildo de jurados como el de Sevilla, con el fin de ofrecer una vía de participación política a las clases medias y bajas. Aun así, el propio rey designó a los representantes del común en la nueva institución de entre los pecheros que consideró oportunos, condenando al Cabildo de jurados desde sus orígenes a una posición contradictoria, en la que sus integrantes, al tiempo que desarrollaban estrategias de ascenso social y consolidaban su poder e influencia, tenían que representar al conjunto urbano y defender los objetivos de la Corona9 ${ }^{9}$ Los regidores tendrían voto en todas las decisiones públicas, mientras que los jurados sólo opinarían, si bien podrían intervenir en cualquier asunto mediante la jurisdicción del rey, apelando a su socorro. De esta forma, Juan II concedió poder a una oligarquía de regidores al tiempo que apoderaba oficialmente a un grupo de oposición, lo que conferiría ciertas particularidades políticas a las relaciones internas de la élite. Además, Toledo tenía otras idiosincrasias: su entramado urbanístico era caótico -lo que en sí suponía un problema para el orden público- $-^{10}$, los conflictos de bandos iniciados en la década de 1440 aun no estaban resueltos a la altura de 1520, y su sociedad padecía una tensión religiosa que, aunque en apariencia sofocada allá por 1495, era una peligro que aún latía ${ }^{11}$.

Más allá de que desde el siglo XIV las instituciones toledanas estuvieran en manos de una enérgica oligarquía de caballeros y hombres de negocios venidos a más, en la década de 1440 la élite política y económica se había fragmentado en dos sectores irreconciliables: el de los Ayala, con el conde de Fuensalida como líder, y el de los Silva, bajo la tutela del conde de Cifuentes. Del mismo modo, desde mediados del siglo XV la sociedad estaba dividida por la parcelación religiosa que entonces se había iniciado, que segmentaba a la sociedad en bloques antagónicos: el de los lindos o cristianos viejos, próximos a los Ayala, y el de los conversos, judeoconversos o

\footnotetext{
${ }^{7}$ Véase: C. Sáez, Sepúlveda en la segunda; E. Corral, Las comunidades castellanas; M. Asenjo, Segovia, pp. 413-417; Y. Guerrero, Organización y gobierno de Burgos.

${ }^{8}$ El mejor estudio sobre la formación de la élite económica, política y social de Toledo en la Baja Edad Media es de J.P. Molènat, y tiene por título Campagnes et monts de Tolède. Interesantes también son los datos e ideas de J.R. Palencia, Ciudad y oligarquía.

${ }^{9}$ El autor que más ha estudiado el Cabildo de jurados de Toledo es F.J. Aranda. Véase la bibliografía citada al final del trabajo.

${ }^{10}$ Ó, López, La población marginada, vol. III, pp. 376-381

${ }^{11}$ El enfrentamiento religioso entre cristianos viejos, o lindos, y cristianos nuevos, conocidos como judeoconversos o marranos, comenzó con contundencia a causa de la rebelión de la ciudad contra Álvaro de Luna y Juan II en 1449. El relato manuscrito de lo que ocurrió entonces se encuentra en: AGS, CC, Diversos, leg. 49, doc. 42. La primera visión de la revuelta de 1449 fue ofrecida por E. Benito, en La "Sentencia-Estatuto"; idem, El Memorial del bachiller; idem, Don Pero Sarmiento; y sobre todo Toledo en el siglo XV, pp. 33-81. Se trata de la visión más o menos "oficial”, completada por visiones parciales centradas en aspectos específicos: R. Gonzálvez, Fundamentos doctrinales; y S. García-Jalón, Los fundamentos jurídicos. La última interpretación en su sentido global de la revuelta ha sido la de B. Netanyahu, Los orígenes de la Inquisición, pp. 193-642, en donde partiendo del convencimiento de que muchos análisis de estos acontecimientos vienen dados desde posturas cercanas, o al menos no críticas, a la acción de los cristianos viejos, se posiciona claramente del lado de los judeoconversos, para realizar una investigación meticulosa en la que plantea nuevas hipótesis. Existe, además, otro trabajo, menos conocido (Netanyahu ni siquiera lo referencia en su bibliografía), de N.G. Round, La rebelión toledana, que, desmarcándose de estas posturas, realiza una interesante, aunque radical, interpretación de la sublevación, como un enfrentamiento entre ricos y pobres.
} 
cristianos nuevos, a quienes de manera ignominiosa llamaban marranos, los cuales siempre estarían más cerca del conde de Cifuentes en busca de protección. El común fue manipulado por unos y otros, y a menudo las consecuencias fueron terribles.

La fe verdadera, la obstinación frente a los Ayala y el desprecio a los Silva, los rumores falsos para pacificar a la población o para encolerizarla, para sublevarse contra el rey o para obedecer su señorío, argumentos en ocasiones espurios y a veces irrefutables, se manipularían para llamar a los no privilegiados a la resistencia pacífica o a la sublevación. Así quedó patente en múltiples ocasiones: en alzamientos como los de 1449 y 1467 , en conjuras como las de 1476 contra la Hermandad y 1481 contra la Inquisición, e incluso en el asesinato de personas prominentes, como el que se produjo en agosto de 1506, cuando unos hombres del marqués de Villena agredieron al jurado Diego Terrín hasta dejarlo sin vida ${ }^{12}$. No hay duda que ya en la década de 1490 los inquisidores habían calmado bastante la situación, y que por entonces los Silva disfrutaban de una preeminencia notable, pero incluso la estructura urbanística de Toledo era un peligro para la paz, como se señaló. El Tajo rodeaba su confusa planimetría por tres frentes, a excepción de por el norte, en donde se encontraban las parroquias de San Isidro y Santiago -el área de los arrabales, zona de prostíbulos, de casas de acogida y de un sinfín de tabernas-. El norte de la urbe era peligroso por el tipo de sujetos que allí residían: hombres sin dueño nin señor conosçido, rufianes y prostitutas, vagamundos y toda clase de gente que pululaba por la nutrida concentración de hospitales de aquel barrio. Empero, cualquier rincón de la urbe era óptimo para perpetrar un delito o promover un escándalo. Las calles serpenteantes y caóticas, estrechas y oscuras, empinadas y sin una dirección evidente, podían convertirse en una trampa. Sin embargo, eran el espacio vital del común de Toledo.

Los miembros del Cabildo de jurados eran quienes se encargaban de la organización de la defensa del orden público, en las parroquias. Para los vecinos su iglesia parroquial tenía una significación práctica: era el símbolo más notorio de su comunidad ciudadana más próxima, el centro de reunión totémico de los ciudadanos, que servía para robustecer el consenso social. Allí se congregaba la población para rezar, oír misa, charlar o hacer negocios. Las parroquias estructuraban a la urbe en barrios con una sociabilidad propia ${ }^{13}$, en los que la vida no era muy diferente de la de la pequeña aldea.

Los vecinos estaban para acompañar, compartir, ayudar y sancionar o prohibir. Se tejían así las redes de la sociabilidad ciudadana que integraban a los individuos a la vez en un territorio, en vínculos de sociabilidad de persona a persona de diferente estatus y condición, y en acuerdos entre iguales. Estos vínculos enmascaraban las contradicciones primordiales, moderaban los enfrentamientos y contenían los impulsos, al tiempo que elaboraban y defendían unos valores y maneras de vivir, que tendían a hacerse comunes a las clases media y baja ${ }^{14}$.

Las parroquias eran el ámbito en el que se hacía palpable la existencia de la comunidad; término sobre el que se ha debatido mucho -más que sobre la palabra "común"- por su relevancia en algunas insurrecciones, que podría definirse como la sociedad legalmente de la urbe, es decir, como los vecinos del núcleo de población,

12 Ó. López, La sociedad amenazada, pp. 302-303.

${ }_{13}$ J.M. Monsalvo, Las ciudades europeas, p. 244.

${ }^{14}$ M. Asenjo, El ritmo de la comunidad, p. 192; idem, Espacio y sociedad, p. 145 y ss. 
más allá de su estatus político, económico, jurídico y cultural ${ }^{15}$. En algunos casos se trata de un término difícil de esclarecer, aunque, por contra, para las gentes del siglo XV su definición era sencilla. En la documentación toledana de fines de la Edad Media todas las apelaciones a la comunidad aparecen en boca del pueblo llano -herreros, tundidores, tejedores, jubeteros-, nunca de las élites, y sólo en los momentos de tensión, cuando comenzaba a percibirse (objetivamente o no) una fractura en la convivencia; en una convivencia que se presuponía innata a la propia comunidad.

Toledo poseía 21 parroquias. En los últimos años del siglo XV las más pobladas eran las de Santiago del Arrabal, San Nicolás, Santa Leocadia, Santa María Magdalena, San Pedro y Santo Tomé. Cada una tenía derecho a elegir a dos jurados, cuyas funciones substancialmente eran defender al rey y a sus vecinos frente a toda clase de abusos, controlar a los gobernantes, hacer cumplir los privilegios de la ciudad, establecer un control sobre la hacienda pública, censurar los nombramientos de oficios concejiles -veedores, fieles, alcaides- que efectuaban los regidores, realizar los padrones vecinales necesarios para la tropa de la urbe, la vigilancia de la población y el cobro de tributos, validar el reparto de dichos tributos entre la ciudadanía, encargarse del abastecimiento de los productos de primera necesidad y, por último, dirigir el sistema de policía que se encargaba de mantener el orden. Por su posición política los jurados exhibían un puesto preeminente en la comunidad: no estaban en la cúspide, como los regidores, en su mayoría caballeros, pero estaban por encima del común, aunque perteneciesen a él, siquiera en sus orígenes.

Dada la trascendencia de su cometido, y puesto que eran los representantes de las parroquias frente a las instituciones, Juan II había concedido a la ciudadanía el derecho a elegir a sus jurados en 1422, de manera que, a pesar de la irrefrenable oligarquización de los organismos públicos, en Toledo, como en otras urbes, el común había logrado mantener un órgano asambleario que se juntaba en las iglesias parroquiales a la hora de elegir a un nuevo jurado ${ }^{16}$, y que posiblemente en los primeros tiempos actuó con cierta libertad, lo que serviría para mantener una cohesión entre los menores. Con los años, no obstante, los omes poderosos, los reyes, la justicia y el Ayuntamiento, por este orden, acabarían con cualquier viso de independencia. Si en un principio parecía que la Corona apostaba por mantener cierta intervención popular en los asuntos públicos, no hay duda que ya en 1422 los actores del común en el Ayuntamientos estaban condenados a alejarse del grupo social del que habían surgido, para, irremisiblemente, integrarse en el sector más bajo de la oligarquía que mandaba en la urbe. La metamorfosis de los jurados era cuestión de tiempo. Desde sus orígenes era evidente que pasarían de ser el grupo más poderoso del común (por influencia y recursos económicos) al menos poderoso de la oligarquía (por capacidad política). Mejorarían su estatus dentro de la comunidad, pero a costa del perjuicio del común en su conjunto. En todas las ciudades donde había representantes del pueblo llano (personeros, sexmeros, cuadrilleros, ochaveros, diputados, jurados, quatros, quarentales) aconteció lo mismo en el siglo XV, fruto de una paulatina oligarquización de las instituciones públicas.

Hasta la reforma de las instituciones municipales de 1422 los medianos y los menores podían intervenir en el gobierno presentándose en las asambleas de los dirigentes y dando su opinión. Al igual que en las juntas vecinales que se celebraban en las aldeas, en las que tenían lugar en Toledo sólo los vecinos mayores de edad estaban autorizados a intervenir. La población era convocada a campana tañida a

15 Sobre esta interpretación véase: J. Martínez, Participación en el gobierno.

${ }^{16}$ M.I. del Val, Ascenso social, p. 163. 
un sitio fijo - una plaza, una iglesia, el portal de un templo- ${ }^{17}$, y una vez reunida los gobernantes explicaban los motivos de la reunión, se oían las opiniones al respecto y se votaba lo que fuese oportuno. Un escribano recogía lo acordado y luego, a ser posible un día de fiesta, se pregonaba por los lugares más concurridos. Era una forma de gobierno en comunidad que llegó a ser útil en algunas poblaciones, normalmente en las que contaban con menos de mil vecinos, pero que pronto manifestó su invalidez a la hora de controlar a una multitud como la que residía en Toledo ya a finales del siglo XIV. Eso fue, precisamente, lo que obligó a inmiscuirse a Juan II en 1422, si bien el problema estaba resuelto de algún modo cuando la monarquía decidió actuar. Lo imposible de responder a lo opinado por centenares de personas había hecho que una pequeña élite desde pronto, ya en el siglo XII, procurase alejar a la población de los asuntos de gobierno ${ }^{18}$, de forma que las reuniones ciudadanas acabarían degenerando en conciliábulos de omes poderosos, en los que la defensa de los intereses personales se anteponían a la búsqueda del bien común. Y sin más, así se acabó aceptando, pese a que a fines del siglo XV algunas parroquias aún reclamaban su derecho a intervenir en política. En su opinión, desde tiempo inmemorial la Corona había apostado en Toledo por la existencia de instituciones públicas en las que pudiera escucharse a todos los vecinos, como probaba la creación del Cabildo de jurados ${ }^{19}$.

Cuando en 1422 Juan II estableció el Regimiento, dejándolo en manos de unos cuantos hombres, a los que se les asignó la tarea de dirigir la urbe, el rey decidió instaurar el Cabildo de jurados para que el pueblo tuviera en él a su órgano de representación más notable. Gracias a ese Cabildo los menores no perderían todos sus derechos políticos, pues sobre sus espaldas recaería la responsabilidad de conceder los títulos de jurado a las personas que los merecieran, a los hombres que eligiesen como sus representantes con el voto de las parroquias. Los jurados serían una fuerza de oposición a los regidores, aunque solo tendrían un poder efectivo con el apoyo de los monarcas, ya que nunca se pensó en ofrecerles el derecho a votar en el Ayuntamiento. De igual forma, la capacidad de los parroquianos para poner a sus representantes sería exigua, pues se haría palpable solamente cuando hubiera que elegir a un nuevo jurado. Hasta entonces sería imposible echar de su oficio a los dueños de las juradurías, a no ser que se contara con el socorro de personas poderosas ${ }^{20}$. Por otra parte, el propio Juan II distinguió como jurados a quienes consideró oportuno, sin oír al pueblo, por lo

${ }_{17}$ No se han conservado documentos que especifiquen de forma clara como estaban reguladas estas reuniones, pero parece evidente que para participar en ellas era necesario ser vecino de la urbe. Seguramente los moradores no podían hacerlo, y desde luego tampoco los foráneos. En las aldeas a partir de mediados del siglo XIV también se detecta una cierta concentración de las labores de gobierno en las manos de unos cuantos individuos. Aun así, a finales del siglo XV los campesinos todavía gozaban de cierta libertad de actuación en sus juntas. Véase al respecto: Ó. López, Control político, pp. 186-292. Un texto datado el 22 de junio de 1376, por ejemplo, dice: "estando ayuntados el conçejo del dicho logar Yepes, e Pedro Martínes, e Garçía Péres, alcalles, e Martín Ferrándes, alguacil del dicho logar, a canpana rrepicada en el portal de la eglesia de San Benito dende": J.P. Molènat, Campagnes et monts de Tolède, p. 537. El 27 de agosto de 1426 se reunieron en el lugar de Alcubillete, del arzobispo de Toledo, además del alcalde y el alguacil "el conçejo e omes buenos del dicho logar Alcubillete a canpana rrepicada": ibidem, p. 538.

18 Véase al respecto: Ó. López, Paz social y marginación.

${ }^{19}$ Sobre la instauración de los Regimientos cerrados véase: J. Abellán, Ordenanzas sobre el regimiento; J.M. Monsalvo, La sociedad política y M.I. del Val, Oligarquía versus común.

${ }^{20}$ El testimonio de los vecinos de la parroquia de San Martín resulta explícito al respecto. En una misiva al Cabildo de jurados se quejaban de la grand falta que había "en la dicha yglesia e perrochia, asý de las cosas conçernientes al serviçio de la yglesia como al bien general e particular de los perrochianos d'ella, por non aver jurados de la dicha yglesia, porque el uno, que es el fonrrado Juan Núñez, que bive en la villa de Madrid, pocos ay en la perrochia o ninguno que le conozcan, e ha veynte años 
que desde sus orígenes el Cabildo pasaría a ser la plataforma para entrar en política de aquellos hombres que consiguieran notoriedad en los negocios y entre el vecindario. Aun así, para el común los jurados eran una salvaguarda frente a las injusticias, aunque procediesen al margen de sus solicitudes.

Se suponía que una vez fallecido un jurado, o tras renunciar a su puesto, su parroquia debía reunirse para elegir a su sustituto entre una serie de aspirantes. Para poderse presentar al oficio de jurado había que ser hombre, mayor de dieciocho años, vecino de la parroquia de la juraduría vacante, y contar con el beneplácito de un buen número de ciudadanos, de las autoridades públicas y, sobre todo, de hombres influyentes. En 1475, por ejemplo, la reina Isabel ordenó que Juan Serrano -hijo de un jurado de la parroquia de San Andrés del mismo nombre- fuera elegido sucesor de su padre por su fidelidad, y porque el conde de Cifuentes se lo había pedido ${ }^{21}$.

Con el discurrir de los años la voz de la parroquia poco a poco fue apagándose, y en la época de los Reyes Católicos los vecinos ya apenas contaban. Claro que el común jamás había llegado a ser totalmente libre a la hora de elegir a sus representantes - por mucho que dijera lo contrario el discurso paternalista de la Corona-, pero fue el tiempo el que hizo irrebatible esta realidad. En la década de 1470, sin ir más lejos, cuando una juraduría vacaba, por la razón que fuese, se notificaba a los jurados en una de las reuniones que solían celebrar los sábados. El asunto era debatido, si había alguna cosa que debatir, y entre los candidatos propuestos por los propios jurados, no por la parroquia, se elegía a uno. En la mayor parte de las ocasiones ni siquiera se necesitaba un debate, ya que solo había un candidato: normalmente un familiar de la persona que dejaba el puesto expedito ${ }^{22}$. Otras veces eran los reyes los que, en virtud de su poderío real absoluto, concedían puestos de jurados -incluso de nueva creación-en recompensa por los servicios que se les prestaban, aunque para tal fin se vulnerase el derecho de las parroquias ${ }^{23}$. Los reyes requerían una y otra vez que los oficios públicos quedaran en manos de sus candidatos, por mucho que la gente de la urbe no quisiera. Lo que sucedió con Alfonso García en 1463 es paradigmático, en este sentido. Dueño de una de las juradurías de San Antolín, y, según aseveraba, no pudiendo trabajar en ella como sería deseable, la renunció en su parroquia, que eligió como su sustituto a Pedro de Ciudad. Unas jornadas después, aunque el nuevo jurado había hecho el juramento de su oficio ante el alcalde mayor, Enrique IV le desposeyó

e más tienpo que no entró en esta çibdad (...) e el otro ofiçio de juraduría que fue del jurado Alfonso de León, defunto, ya saben vuestras merçedes que está vaco".

${ }^{21}$ AGS, RGS, 15 de agosto de 1475, f. 559.

${ }^{22}$ Por ejemplo, Diego de Escarramán, jurado de la collación de Santo Tomé, consiguió en 1475 una licencia de la reina Isabel por la que le permitía que su hijo Pedro de Escarramán pudiera ejercer como jurado cuando él no pudiera hacerlo, y después de muerto: AGS, RGS, 30 de octubre de 1475, f. 644 .

${ }^{23}$ En este sentido, es interesante el testimonio que se recoge en una carta enviada por un jurado que estaba en la corte a su Cabildo, informando de sus gestiones para impedir que el rey impusiera a un candidato propio en un oficio público de la ciudad. Según el jurado, el rey le había dicho cuando le comentó el caso que él no quería quebrantar los privilegios de Toledo, pero que "los reyes ovieron poder de dar aquellos ofiçios": AMT, "Este libro es de traslados", Sección B, núm. 120, f. 167r-v. Un caso parecido, de 1468, en la parroquia de San Juan de la Leche, en BNM, ms. 13.110, ff. 17r-18v. En 1478, la reina Isabel decía en una merced a favor de Fernando de la Fuente, hijo del jurado Pedro de la Fuente: "mando a los dichos mis jurados que manden a los vesynos e perrochanos de la dicha yglesia de Sant Biçente que vos ayan por su jurado, e usen con vos en el dicho ofiçio": AGS, RGS, 5 de agosto de 1478 , f. 6 . 
de la dignidad alegando razones de carácter jurídico ${ }^{24}$, lo que solía ocurrir cuando los reyes estaban en problemas y había dudas sobre la sumisión de los hombres que gobernaban Toledo.

A fines del siglo XV el procedimiento habitual era el siguiente. Una vez que un oficio se renunciaba y un candidato era propuesto, los jurados pedían a su escribano que convidase a la parroquia. La votación popular del candidato era un requisito ineludible, puesto que, según las palabras de la época, desde 1422 la memoria de ombres no era en contrario. Por ley, los parroquianos se debían juntar en su iglesia a ejercer su derecho al voto, más allá de que dicho derecho se hubiera manipulado previamente.

De un total de quince reuniones celebradas entre 1479 y 1486 para nombrar a un jurado el grupo de vecinos más numeroso que se convidó lo tenemos en la parroquia de San Román, cuando en 1483 se llama a 148 hombres para que acudan a dar sus pareceres en la designación como su representante de Juan Ruiz ${ }^{25}$, en quien había renunciado Payo Correa. No obstante, solo acudirían 50, y de ellos 15 (casi todos judeoconversos) no eran de los convidados ${ }^{26}$, lo que evidencia que si bien a las reuniones podían acudir todos los vecinos se daba prioridad a algunos, a los que se convidaba personalmente por su influencia social, su estatus económico o sus relaciones personales. Según la documentación, el número de hombres que se convidaba iba -al parecer según el tamaño de la parroquia- de 50 a 100, con una variación de unos 20 por arriba o por abajo, pero el número de los que asistían casi nunca llegaba a la mitad. En 1484, por ejemplo, en la parroquia de San Andrés fueron convidados 92 vecinos, y acudieron $23^{27}$. En 1486 se convidó a 39 en la de San Antolín y solo asistieron $12^{28}$. En San Cebrián, en 1482, de 59 se presentaron $20^{29}$, y en la de los Santos Justo y Pastor, en 1480 , de 112 solo $55^{30}$.

${ }^{24}$ AMT, "Este libro es de traslados", Sección B, núm. 120, f. 98r-v. Algo parecido sucedió cuando Alonso Romero renunció su juraduría en Diego de Montoya, en 1517. Diego de Montoya fue recibido por el Cabildo de jurados y los parroquianos lo aceptaron, pero el alcalde mayor, en virtud de una cédula del regente de Castilla, el cardenal Cisneros, se negó a aceptar la renunciación (ibidem, f. 149r).

25 AMT, ACJ, DO, “Actas capitulares (1470-1487). Cuentas, cartas, varios”, caja. 23, reunión del 26 de diciembre de 1486, ff. 198r-sin foliar vuelto; AGS, Guerra y Marina. Guerra Antigua, leg. 1314, doc. 60, pliego 2, parroquia de San Román.

${ }^{26}$ Alfonso de Toledo, Alfonso Rodríguez Carranque, Fernando González de la Cruz, Fernando Sánchez, Fernando Vázquez, Francisco de Acre, Francisco Fernández Golondrino, Francisco Rodríguez Valenciano, Gonzalo Rodríguez, Gutierre Cambiador, Juan del Campo, Juan Jiménez de Toledo, Pedro Hayete, Pedro Fernández Golondrino y Rodrigo de Toledo. Pedro Fernández Golondrino, por ejemplo, estaba casado con Teresa Vázquez, y era escribano. En 1497 él y su mujer se tuvieron que reconciliar con la Inquisición (F. Cantera, P. León, Judaizantes del Arzobispado de Toledo, p. 50). En 1503 tenía unos 60 años: AGS, Guerra y Marina. Guerra Antigua, leg. 1314, doc. 60, pliego 2, parroquia de San Román).

${ }^{27}$ El jurado de esa parroquia, Diego Sánchez de Toledo, hizo renunciación de su oficio a favor de su hijo Tomé Sánchez, advirtiendo que en caso de que éste no fuera aceptado en el cargo el oficio pasara a manos de su cuñado Juan de Santamaría. Al final aceptaron a Tomé Sánchez: AMT, ACJ, DO, "Actas capitulares (1470-1487). Cuentas, cartas, varios", caja. 23, reunión del 11 de diciembre de 1484 , ff. 254 r-259v.

${ }^{28}$ Se puso a Juan Pérez Vallejo, que era uno de los tres jurados que por entonces había en la parroquia de San Bartolomé de San Soles, en la de San Antolín, cuando los inquisidores inhabilitaron a Pedro de Uceda, el jurado de ésta: ibidem, reunión del 15 de junio de 1486, f. XIIr-v.

${ }^{29}$ Ibidem, reunión del 16 de septiembre de 1482 , ff. $183 \mathrm{r}-187 \mathrm{v}$.

${ }^{30}$ Tras la muerte de Luis de Segovia, jurado de los Santos Justo y Pastor, se decidió que, como estaba ordenado por los reyes, un jurado de los que poseía un oficio de los acrecentados (Alfonso de 
Aunque no se conservan documentos que especifiquen las normas que se seguían a la hora de convidar a los parroquianos, parece ser que elegir a sus representantes políticos era un derecho de los vecinos, no de los moradores, es decir, un derecho de los que conformaban la "comunidad jurídica" de Toledo ${ }^{31}$, no de la "comunidad imaginada" -concebida por la población-, a la que se apelaba no por razones legales sino escarbando en sentimientos de pertenencia al grupo, en los que las ideas religiosas eran imprescindibles. En la década de 1450, y sobre todo a raíz de la rebelión de 1449, la comunidad de Toledo se fragmentó en dos grandes sectores, cristianos viejos y judeoconversos, que en la época en que se instauró el Cabildo de jurados aún no eran evidentes, por lo que Juan II dio buena parte de las juradurías a un grupo de linajes pecheros enriquecidos gracias a sus actividades comerciales que, de esta forma, con la ayuda del rey y sin mirar su origen religioso, pasaron a ingresar en el gobierno con un papel a medio camino entre la oligarquía y el gran grupo del común. Más tarde, tras la revuelta de 1449, y hasta que la Inquisición hubo "limpiado" las instituciones públicas de (en teoría) falsos conversos, allá por 1495, la desconfianza popular se cebó con esos linajes de raíces judías que ostentaban oficios de jurados (y escribanos públicos). Enrique IV, incapaz de hacer frente al problema, se limitó a otorgar juradurías a individuos que no despertaban rechazo por su origen, haciendo que el número de jurados ascendiese a la increíble cifra de setenta y dos a principios de la década de 1470, si bien no pudo evitar ni que el rechazo continuase ni que, de alguna forma instigada por el mismo, la relación jurados-ciudadanía se diluyese, haciéndose mecánica, fruto de una obligación institucional, no de una verdadera representatividad política. A partir de 1485, apenas llegada a la urbe, la Inquisición depuró a los jurados, entre otras razones para mejorar la opinión pública que de ellos tenían los cristianos viejos $^{32}$, pero aun así los problemas no se resolvieron, y la oligarquización endogámica de su Cabildo continuó.

Unos jurados a los que sus propios compañeros designaban eran quienes tenían la misión de tramitar el nombramiento del nuevo jurado. Para tal fin, junto a su escribano, tenían que recorrer las calles del distrito parroquial de la juraduría vacante convidando a la población. El sistema no era complicado. Pese a ello, si se comparan las informaciones de un alarde de 1503 y las listas de convidados las cuentas no cuadran $^{33}$. El alarde dice, por ejemplo, que en Santa María Magdalena había 323 vecinos, y en 1483 únicamente acudieron a una junta para elegir a uno de sus jurados $35^{34}$. De igual modo, si en 1503 en San Juan de la Leche había 106 vecinos, los convidados a sus juntas no pasarían jamás de $40^{35}$. La disparidad de cifras se debe, entre otras

Zatres) sobre una parroquia mozárabe, en este caso la de Santa Olalla, pasara a convertirse en jurado de la parroquia latina cuya juraduría vacó, consumiéndose la juraduría acrecentada: ibidem, reunión del 22 de mayo de 1480, ff. 82r-85v.

31 Véase: F. Martínez, El régimen jurídico.

32 Algunos jurados quisieron evitar la llegada del Santo Oficio a Toledo a través de una conspiración que fue un fracaso, y que no hizo sino azuzar todavía más la inquina hacia los conversos: Ó. López, Los Reyes Católicos, pp. 251-252.

${ }^{33}$ Sumando el número de parroquianos convidados y presentes en las reuniones celebradas, solo las parroquias de San Salvador, San Soles y San Román dan una cifra similar a la que aparece en el alarde de 1503 .

${ }^{34}$ Renunció la juraduría de esta parroquia Rodrigo de Atienza en Juan Vázquez, quién cambió esta juraduría con Fernando González Husillo por una de los Santos Justo y Pastor: AMT, ACJ, DO, "Actas capitulares (1470-1487). Cuentas, cartas, varios", caja. 23, reunión del 15 de marzo de 1483, ff. $214 \mathrm{r}-215 \mathrm{r}$.

35 En lugar de Diego de Varcárcel, que había fallecido, recibieron como jurado al licenciado Francisco Ortiz: ibidem, reunión del 30 de octubre de 1481, f. 151r-v. 
razones, al hecho de que los jurados elegidos para convidar a la parroquia fueran casi siempre los mismos que daban noticia a su Cabildo de la renuncia del puesto vacante, pues el beneficiado por la misma solía ser un pariente o alguien próximo. En consecuencia, quienes realizaban el convite tenían un interés especial en que el oficio sin dueño quedara en manos de la persona que -con la venía de su Cabildo- ellos representaban, lo que sumado a la premura con que se solía realizar el convite, en una tarde apenas, hacía que se convidara solo a las personas afines, a las que se considerase que iban a votar al candidato sin objeción. Por ende, las clientelas sociales eran básicas en las votaciones de los jurados.

La jornada del convite los jurados convidadores iban de calle en calle y de puerta en puerta para informar sobre la renuncia de la juraduría y sobre la asamblea para elegir al nuevo representante de la parroquia. Las listas de convidados conservadas recogen los nombres de a quienes se informó en la tarde del convite, si bien las razones por las que no aparecen todos los parroquianos son múltiples. Sabemos que algunas de las puertas a las que llamaban los convidadores no solían abrirse, porque en el edificio no había nadie o porque sus dueños no deseaban abrir, y en las calles no siempre había mucha gente -sobre todo en el invierno-, así que los jurados a menudo se topaban con pocas personas. Además, había vecinos a los que intentaba esquivarse por su tirante relación con el sujeto que pretendía el oficio público o con su familia, por no ser conocidos o por muchos otros factores. Por otro lado, era a través de las personas convidadas como debía extenderse la noticia de que se iba a elegir a un jurado, pero apenas se les daban unas cuantas horas para propagar del mensaje. Por último, el convite iba dirigido especialmente a las personas fieles a los linajes o individuos que aspiraban al puesto, es decir, a clientes que a cambio del apoyo que se les solicitaba recibirían compensaciones económicas o jurídicas en su momento por parte del futuro jurado. Esto explicaría, en esencia, el que casi nunca se convidara ni al $50 \%$ de la parroquia, y el que de los convidados en la mayor parte de las ocasiones no acudiese a la cita ni la mitad ${ }^{36}$-las mujeres quedaban al margen-. Solo el $25 \%$ de los vecinos solía acudir a las juntas para elegir a sus jurados.

Las causas por las que un vecino acudía o no a sus reuniones eran variadas. La mayoría lo consideraba un asunto de conveniencia; para tener una buena relación con el sujeto y/o el linaje que aspiraba al oficio. Otros, por el contrario, no se sabe qué número, querrían ejercer uno de los pocos derechos que el siglo XV les quedaban a los toledanos. De cualquier forma, la manipulación de las asambleas era irremediable. Por ejemplo, si excepcionalmente se habían de celebrar dos o más reuniones para elegir a un jurado lo habitual era que a la segunda se convidaran y acudiesen menos vecinos, pues solía convocarse en día de trabajo o a horas desacostumbradas ${ }^{37}$, con el objetivo de favorecer la asistencia de sólo algunos sujetos ${ }^{38}$.

${ }^{36}$ Por ejemplo, en la elección de un jurado de los Santos Justo y Pastor que se realizó en 1480 fueron invitados 111 parroquianos y acudieron 55. De ellos 18 no habían sido invitados: Alfonso del Rey, Alfonso Rodríguez, Antonio de Sevilla, Antonio Rodríguez, Damián, Diego Terrín, Fernando de Benavente, Fernando de Frías, Fernando Herrero, Francisco de Toledo, García de la Calle, Gonzalo Carpintero, Juan de Medina, Juan de Toledo, Juan Ruiz, Pedro Zurrador, Pedro López y Sancho de Burgos (AMT, ACJ, DO, “Actas capitulares (1470-1487). Cuentas, cartas, varios”, caja. 23, reunión del 22 de mayo de 1480, ff. 82r-85v).

${ }^{37}$ En 1483 Payo Correa renunció su oficio de jurado de la parroquia de San Román en Juan Ruiz, hijo del jurado Alonso Ruiz. En la reunión celebrada el 29 de diciembre de 1483 los parroquianos dijeron que no aceptaban la renuncia. Posteriormente fueron convocados el martes 21 de enero de 1483 a hora de vísperas. En esta reunión finalmente sí lo aceptaron.

${ }^{38}$ Por ejemplo, la primera reunión que se celebró en 1486 en San Bartolomé de San Soles, a la que se invitó a 78 personas y vinieron 27, tuvo lugar el jueves 9 de marzo a primera hora de la 
Una vez con los vecinos en la iglesia se procedía a la ratificación popular del candidato. El 28 de febrero de 1484 se anunció en una reunión de los jurados que uno de ellos, Sancho Fernández, dejaba su juraduría en manos del Cabyldo e de los perrochianos de Sant Ysidro, en favor de Alfón de Santamaría, con retençión sy no fuese resçibydo segúnd costunbre del Cabildo ${ }^{39}$. Esta cláusula era frecuente. Los oficios se otorgaban a familiares y allegados con la condición de invalidar la renuncia si no era permitida, aunque lo común solía ser, como pasó en el caso de Sancho Fernández, que se aceptara y se convidase a la perrocha segúnd costunbre. Para tal fin, en febrero de 1484 se diputó al mayordomo del Cabildo, Jaime de Morales, al bachiller Francisco Ortiz, a Luis de Vitoria, a Rodrigo Cota (el otro jurado de San Isidro) y a Juan de Santamaría, pariente de la persona que aspiraba al oficio, y la misma tarde del día 28, a ora de vísperas, fue conbidada la perrocha. Según el acta del escribano del Cabildo,

andovieron todas las casas de la dicha perrocha e conbidaron a los dichos perrochanos, d'ellos en sus casas, e d'ellos en persona, para que mañana a prima vayan a la dicha perrocha de Sant Ysidro a ver una renunçiaçión que un jurado quiere faser de su ofyçio e faser la elecçión segúnd su costunbre, con aperçibymiento que los que fueren farán por todos ${ }^{40}$.

En total se convidó a 49 parroquianos, pero el domingo 29 a la hora de prima en la iglesia de San Isidro sólo se contaban 25 hombres, algunos ni siquiera convidados, aparte de los jurados Luis de Vitoria, Diego Sánchez de Toledo, Juan de Santamaría, Rodrigo Cota y Alfonso de Santamaría, aspirante al puesto. Los jurados dieron fe a la parroquia de la renuncia del oficio público que se había realizado en favor de Alfonso de Santamaría, y le advirtieron que su Cabildo la había aprobado, tras lo cual los presentes, syn mucho fablar en ello, de un acuerdo e voto, señalaron que les placía la renuncia, pues el aspirante al oficio era su pariente e vesino, e fijo de Juan de Santamaría, de quien ellos todos avýan resçibido muchas buenas obras; e por eso que ellos lo elegían por su jurado. Eran las palabras de los clientes del linaje de los Santamaría. No en vano, tras la aceptación de la persona propuesta -y siguiendo la costumbre- los parroquianos deberían haber alzado a Alfonso al tiempo que vociferaban comunitariamente (era la voz de la parroquia) ;Aquí vedes a nuestro jurado. ${ }^{41}$. Pero no fue necesario. La costumbre establecida no hizo ninguna falta. Lo usual era que después de informar de la renuncia los jurados saliesen de la iglesia para que la parroquia pudiera debatir sin ninguna intromisión, y luego se les llamaba para informarles de su parecer. No obstante, cuando se eligió a Santamaría los jurados ni siquiera se fueron de la iglesia. Los asistentes a la junta, hombres próximos al candidato y su familia, lo aceptaron sin más, según habían previsto los jurados convidadores, y el día siguiente, lunes 1 de marzo, el nuevo jurado prometió sufragar una comida a sus compañeros y conceder a su Cabildo 500 maravedíes -dos requisitos obligados- antes de presentarse en el Ayuntamiento para jurar su oficio.

mañana, y ese mismo día el jurado elegido se presentó en el ayuntamiento: AMT, ACJ, DO, “Actas capitulares (1470-1487). Cuentas, cartas, varios”, caja. 23, reunión del 9 de marzo de 1486, ff. VIIrsin foliar.

${ }^{39}$ Ibidem, reunión del 28 de febrero de 1484 , f. $229 \mathrm{v}$.

${ }^{40}$ Ibidem, reunión del 28 de febrero de 1484, f. 230r.

${ }^{41}$ En los documentos se dice que los parroquianos "tomáronle en peso", con los pies en alto del suelo, y decían “¡vedes aquí a nuestro jurado!”: ibidem, reunión del 28 de diciembre de 1483 , ff. 198 r-sin foliar vuelto. 
Esta forma de elegir a Alfonso de Santamaría en ningún caso es excepcio$\mathrm{nal}^{42}$. Cada vez con mayor frecuencia las elecciones populares de los jurados acabarían convirtiéndose en un trámite sin valor para el común, en el que personas afines a los candidatos elegidos ratificaban una elección ya hecha ${ }^{43}$. Desde como poco la década de 1460 sería usual que los caballeros, los regidores y los jurados presionaran para conceder las juradurías a las personas que les interesaba, sirviéndose de toda clase de intimidaciones. Al vacar una juraduría,

siempre andaban buscando et procurando votos para aver los tales ofiçios para criados et amigos suyos, o para otras personas por quien an gana de hazer, a cuya cabsa dis que acaheçe aver los tales ofiçios personas que no son ábiles ni sufiçientes para ellos ${ }^{44}$.

Por la forma en que se otorgaban, las juradurías -y los cargos menores del Ayuntamiento cuyos titulares eran elegidos por los regidores: fieles ejecutorías, almotacenazgos, alcaidías, veedurías- se convirtieron en un artilugio para hacerse una clientela, y los omes poderosos no lo desaprovecharon. Las juradurías sirvieron, por una parte, para aumentar la influencia de los caballeros, de la "élite de poder" ${ }^{\prime 5}$, y por otra, para consolidar el ascendiente de la élite del común, a la que José Antonio Jara Fuente denomina "élite de participación" ${ }^{4}$. El vecindario en su conjunto quedó marginado, tuvo que claudicar ante la preeminencia de las redes clientelares, y de acudir a votar lo hizo bajo amenaza y temeroso, bajo la coacción de sujetos que querían imponer su voluntad ${ }^{47}$. A veces, incluso, la juraduría se convirtió en objeto de especulación económica con fines privados. Se cambiaba por otro puesto, se vendía por una buena suma de maravedíes o se arrendaba al mejor postor $^{48}$. La ley y los privilegios de los jurados prohibían estas prácticas, pero no servía de mucho. Los sobornos, las amenazas, las promesas y las arbitrariedades estaban a la orden del día ${ }^{49}$. El oficio de jurado, aun sin la influencia política de un regimiento, comportaba una serie de privilegios apetecibles para las familias enriquecidas de mercaderes. Los jurados estaban exentos de tributos y no podían ser encarcelados por deudas.

${ }^{42}$ En la reunión que se realizó el 9 de marzo de 1486 en la parroquia de San Bartolomé de San Soles para elegir como jurado a Diego de Vargas, los parroquianos "syn mucho altercar, e todos de una voluntad e un voto, dixeron que los plasía mucho la renunçiaçión": ibidem, reunión del 9 de marzo de 1486, ff. 11r-12v.

${ }^{43}$ Cuando Diego de Vargas, jurado de la parroquia de San Lorenzo, renunció en su hijo Fernando Vázquez su juraduría, fueron invitados 80 parroquianos, pero tan solo vinieron 37: ibidem, documento suelto.

${ }^{44}$ AMT, ACJ, DO, núm. 60.

${ }^{45}$ Véase la reflexión teórica de C. Jular Pérez-Alfaro en Nuevas cuestiones.

${ }^{46}$ Véase: J.A. Jara, Doble representación y cruce de intereses, pp. 307-308, e idem, Sobre el concejo cerrado.

47 Sólo de forma extraordinaria los vecinos se atrevieron a quejarse de esta situación. Uno de los pocos casos fue el de la parroquia de San Román, en 1486: AMT, ACJ, DO, “Actas capitulares (1470-1487). Cuentas, cartas, varios", caja. 23, reunión del 28 de diciembre de 1483, ff. 198 r-sin foliar vuelto.

${ }^{48}$ Los reyes advirtieron al otorgar una juraduría al bachiller Alonso Pérez de Aguilera, renunciada por su padre Bartolomé de Aguilera, que para que fuera válida la renuncia no debía haber "yntervenydo conpra, ni troque, ni cambyo, ni promutaçión ni otra cosa”: AGS, RGS, 1501-I, Granada, 20 de enero de 1501.

49 Contra estas prácticas, habituales a principios del siglo XVI, advertían tanto los monarcas como los propios jurados: AMT, "Este libro es de traslados", Sección B, núm. 120, f. 298 r-v. 
Desde 1422 las juradurías habían sido un objeto de deseo para las grandes familias de la urbe casi exclusivamente por los privilegios que comportaban. Los linajes de mercaderes buscaban ocupar el máximo número de juradurías vacantes para evadirse de impuestos, y no sólo por el prestigio social y la influencia política que daban los cargos públicos. Así, a la altura de 1510 la desconexión entre los jurados ${ }^{50}$ y los pecheros en su conjunto era inaudita, y la Corona, que ya había intentado resolver un problema parecido mediante la Inquisición (purgando las instituciones de judeoconversos, para favorecer el apoyo de los lindos), en 1512 apostó por atajar la nueva problemática de un modo concluyente, y ordenó que en adelante no fuera proveida de los dichos ofizios de jurados e alguaziles de esa dicha çibdad ninguna persona que [fuese] pechero, salbo personas esemptas de los dichos pechos; y que si algún pechero fuera elegido jurado su elección se anulara ${ }^{51}$. La realeza pretendía así -ansiosa por evitar la corrupción- que los oficios públicos quedasen en poder de personas sin intereses económicos, aunque lo que conseguiría de facto fue alejar al común de una vez por todas del gobierno. Y el común lo asumió; lo que no quiere decir que lo aceptase.

\section{UNA EVOLUCIÓN EN LAS FORMAS DE LA REPRESENTATIVIDAD POPULAR. LAS JUNTAS DE LA CONGREGACIÓN EN ÉPOCA DE LAS COMUNIDADES}

Aunque en el día a día la marginación del común en los asuntos de gobierno se toleraba, no deja de ser interesante que en los siglos XV y XVI siempre que se produjo una revuelta en Toledo el Cabildo de jurados fuese una de las primeras instituciones en sufrir represalias. Era la institución pública de la que el pueblo esperaba más, y por ende la que solía despertar más pasiones, sobre todo si tenemos en cuenta que sus integrantes no pertenecían a la élite de los caballeros, a la que se respetaba por su estatus, sino que se trataba de prósperos comerciantes cuyos orígenes en ocasiones parecían oscuros.

Durante la revuelta de 1449 un grupo de lindos comenzó a hablar en nombre de la Santa Ciudad de Toledo y apartó de la vida pública a innumerables jurados ${ }^{52}$, a quienes se acusó de no defender a su pueblo y de ocultar sus creencias religiosas de carácter judío bajo una careta de fe cristiana. Semejantes críticas nacieron de una convicción enraizada en las mentes de un buen número de vecinos, y aunque las revueltas no lograron gran cosa la actitud crítica frente a los supuestos representantes de la población común caló hondo. En 1467 también se atacó al Cabildo de jurados, y a partir de 1485 los inquisidores se cebarían con sus integrantes, a los que condenaron a perder sus oficios, sus bienes e incluso la vida. Aunque se argumentaba con razones religiosas, el ataque a los jurados también tenía algo de catarsis; de algún modo servía de venganza por la traición de unos hombres que tendrían que haber procedido en todo momento en favor de su grupo, los pecheros, y en contra de la élite, y que aun así se habían dejado embaucar por los poderosos para convertirse en su alter ego.

Ya en las primeras décadas del siglo XVI, durante la rebelión comunera, el pueblo llano intentó cambiar las cosas. Aunque no se abolió, durante el alzamiento de

${ }^{50}$ A finales de la Edad Media la élite pechera que ocupaba la juradurías la integraban las familias De Acre, De Alcalá, Álvarez Zapata, Del Arroyo, De Baeza, De Bargas, Cota, Franco, De la Fuente, De Gómara, Hurtado, Husillo, Jarada, De Madrid, De Navarra, De Oseguera, De San Pedro, Santamaría, Serrano, Terrín y De la Torre: Ó., López, La sociedad amenazada, p. 182.

${ }^{51}$ AMT, ACJ, Reales cédulas y provisiones, caja 20.

52 Véase: E. Benito, Memorial del bachiller. 
1520-1522 el Cabildo de jurados dejó de funcionar. Apenas se produjo la insurrección los vecinos pactaron establecer una institución que les representara como se debía, y que ciertamente se hiciera eco de las ansias de la población humilde. Al principio se pensó que unas simples modificaciones en el Cabildo de los jurados serían suficientes, pero pronto las modificaciones planteadas eran tantas y de tanto calado que se decidió anular el Cabildo y establecer una institución alternativa, fruto del pueblo -no obra de un rey, como las juradurías-, que recibió el nombre de Congregación. Fue una medida en verdad revolucionaria. Ni siquiera durante el mayor alzamiento que se había vivido en la urbe en las últimas décadas, en 1449, los sublevados se habían atrevido a hacer algo así: instaurar un organismo de gobierno fruto de la soberanía de la población obra de menores e medianos-, con poder para intervenir en la vida pública al margen de las instituciones de la Corona. El Cabildo de jurados no desapareció legalmente, pero quedó obsoleto. En señal de ofensa la ciudadanía lo ninguneó, aunque la Congregación fue organizada según el Cabildo, quitando lo que impedía que representase los intereses pecheros:

ciones.

- Podrían ser miembros de la Congregación todos los vecinos, sin excep-

- Cada parroquia (al igual que en el caso de los jurados) aportaría uno o dos diputados, nomenclatura que se puso a los nuevos representantes del común. Las de Santo Tomé, San Nicolás, San Justo y Santiago del Arrabal, entre otras, contarían con dos diputados, mientras que las de San Salvador, San Román, La Magdalena, San Isidro, San Vicente, San Bartolomé, San Juan Bautista, San Cristóbal y San Cebrián tendrían uno.

- Al contrario que los jurados, los diputados serían elegidos anualmente con los votos de sus parroquias, sin que nadie pudiera mediar para que se votase a uno u otro individuo.

- La opinión de los parroquianos tendría un papel esencial en la toma de decisiones por parte de los diputados, que debatirían con ellos los asuntos trascendentes $^{53}$.

- Por último, y aquí es donde estaba la novedad con respecto al anterior Cabildo, si éste no podía votar a la hora de resolver los problemas de la urbe, pues solo el Regimiento ostentaba el derecho al voto, la Congregación tendría un poder ejecutivo idéntico al de los regidores, aunque su origen fuera muy diferente; no emanado del monarca, sino de la Comunidad.

La rebelión de 1520 trajo consigo un cambio rotundo en el sistema de representatividad popular instaurado hasta entonces. Con la vista puesta en un teórico sistema de gobierno popular arcaico desaparecido por la acción conjunta de la Corona y los oligarcas, muchos sectores del común que habían permanecido al margen -sobre todo los artesanos textiles- se implicaron en el gobierno durante 1520 y 1521 , con el fin de cambiar las estructuras de poder; y aunque no conseguirían sus fines, pues la insurrección comunera sólo fue un paréntesis en el proceso de desarrollo de las instituciones públicas, tal insurrección permite observar con nitidez el inconformismo pechero ante la decrepitud de sus órganos de representación política.

Junto al Regimiento, que quedó en manos de regidores facciosos -los leales al monarca habían huido-, la Congregación sustituyó al Cabildo de jurados fundamentándose en su articulación parroquial. La formarían cuatro decenas de diputados (un número similar al de jurados) elegidos por votos, esta vez sí democráticamente, y

${ }^{53}$ F. Martínez Gil, La ciudad inquieta, pp. 152 y ss. 
aunque por la falta de documentos se desconocen los detalles -si había requisitos para votar, prelación en las votaciones o votos de calidad-, es posible que el sistema fuese idéntico al que se empleaba con los jurados, pero sin clientelismos, sobornos ni chantajes. No en vano, en la época de la insurrección comunera la salvaguarda militar y el amparo del orden público también se organizarían partiendo de las parroquias, a partir de tres modelos: el Cabildo de jurados, las hermandades y las Gentes de Ordenanza de 1516 . A partir de 1520 cada parroquia tendría un capitán y varios cuadrilleros, que formarían escuadrones de quince o veinte vecinos cuya labor consistiría, básicamente, en defender la rebelión persiguiendo a los perjuros y a los delincuentes ${ }^{54}$, contando con el apoyo de los alcaides de las fortalezas. Según un escrito,

cuando los dichos alborotadores querían salir a hacer algunas cabalgadas lo hacían saber a las parroquias, para que fuesen con su capitán a donde les mandase, y otros para poner recaudo en la dicha ciudad, diciendo que había muchos traidores en ella, por que no la vendiesen o entregasen [a] algunos caballeros que deseaban entrar en ella. Y que para esto mandaban repicar las campanas y se juntaban en las iglesias: para dar orden cómo habían de salir y lo que querían hacer ${ }^{55}$.

De forma anual, en abril, la Congregación de los diputados elegía a tres procuradores generales del pueblo, uno por cada estado (caballeros, ciudadanos y oficiales), y al escribano de la Congregación, quienes se encargarían de las relaciones con el Regimiento, los jurados, el Cabildo catedralicio y los otros órganos institucionales -Colegio de escribanos, Cabildo de los monederos, Cabildo de los tejedores y cofradías. Los diputados, por su parte, solían reunirse en la casa de la Congregación o en la posada de la Hermandad, donde debatían sobre los más variados asuntos; y cuando tenía que tratarse un tema espinoso se llamaba a campana tañida a las parroquias, que se juntaban en sus iglesias de inmediato, con todos los vecinos por igual, fueran simples peones o caballeros.

En esas pretendidas juntas igualitarias de las parroquias los debates a veces resultaban acalorados. Aunque la posición de los caballeros, por su dignidad, solía influir en la toma de decisiones, también influían, y mucho, "la presión popular y las amenazas de los alborotadores". Dos escribanos tomaban nota de todo, ante los cuáles, dice fray Prudencio de Sandoval, cada uno, por bajo que fuese, daba su parecer. Una vez establecido un acuerdo los diputados se encargaban de decirlo en las asambleas de la Congregación, que tenía la última palabra.

A pesar de lo bondadoso de este sistema, lo cierto es que la manera popular de gestión del poder público ideado por los comuneros, aparte de no ser totalmente novedosa, acarreaba enormes dificultades a la hora de ponerse en práctica. Como no podía ser otra forma, para los caballeros era indignante que el papel de un sujeto con un estatus inferior fuese como el suyo en las juntas de parroquianos, por no hablar del hecho de que una persona symple -un tejedor, un albañil, un pelaire- pudiera convertirse en diputado y mandar sobre los regidores, quienes, según su preheminençia, afirmaban tener derecho a gobernar sobre el resto de los ciudadanos. Por otra parte, si el poder ejecutivo iba a estar en manos de los regidores y la Congregación, ¿de producirse una disparidad de pareceres quién estaría por encima? Era previsible que los regidores se opusiesen a la Congregación ante una dificultad a la hora de hacer su trabajo (por mucho que los procuradores generales del pueblo mediaran en el asunto),

54 M.C. Vaquero, El proceso contra, p. 361.

55 Ibidem, p. 366. 
y eso era algo que sabían bien los comuneros de las clases bajas, el núcleo más radical de los rebeldes, que veía a los caballeros como traidores potenciales que, en caso de tener que elegir, siempre optarían por el Regimiento frente a la Congregación. Sin embargo, el gran problema no era el recelo frente a los poderosos, sino las dificultades a la hora de tomar decisiones.

La forma popular y colectiva de decidir en que se basaba la Congregación, un sistema bastante democrático en teoría, era inviable, y al parecer las pruebas que lo demostraban eran cuantiosas, según la realeza. En 1520 hacía un siglo que en la ciudad del Tajo funcionaba el Regimiento, una institución que se fundó precisamente porque el modo de gobernar colectivo que existía hasta entonces estaba obsoleto. Hasta 1422 las juntas de los gobernantes eran de carácter popular, abiertas a los vecinos, para que en las tomas de decisiones todos ofrecieran su opinión; pero en la práctica nunca fue así: las relaciones de poder entre los oligarcas habían hecho que la política quedase en manos de unos pocos, que la población fuera marginada y que de volver a un gobierno popular fuera factible que la historia se repitiese. Tal vez la discusión en las parroquias en un principio fuera democrática, pero poco a poco se degradaría. Muchas personas, ya se ha dicho, opinaban que los caballeros por rango habían de poseer mayor preeminencia a la hora de tomar decisiones, mientras que otros, con ideas radicales, estaban en contra, y acabarían alborotando las juntas para que su voluntad se impusiese. En consecuencia, por sumisión al estatus de los poderosos o por las coacciones de los más furibundos, las "juntas igualitarias" de parroquianos se convertirían en un problema. Así nos lo señalan los documentos conservados.

A quienes no acudían a las juntas se les tachaba de traidores, al igual que a aquellos que, presentándose, exhibían una opinión que discordaba con el pensamiento mayoritario o con los extremistas. Esto hizo que muchos empezasen a temer que sus posturas no se consideraran lo suficientemente comprometidas con la Comunidad. Pedro de Teba, por ejemplo, concluida la sublevación dijo en el proceso contra Juan Gaitán -con el fin de disculparse por su papel en la revuelta- que a las juntas de la parroquia donde él habitaba, Santo Tomé, iban otras personas que no eran de la parroquia y contradecían todas las cosas que se decían en servicio de Dios y de Sus Majestades ${ }^{56}$. A él lo quisieron matar únicamente por contradecir a unos radicales, y que si no fuera por Dios y el cura de la dicha parroquia, y algunos buenos que allí estaban, le mataran. Fray Rodrigo de Fuente de Campos señaló, por su parte, que

no había persona que osase hablar a favor de ninguno bueno (...) había personas malsines por la dicha ciudad de Toledo para oír lo que se decía, y que no osaba ninguno hablar cosa que fuese en disfavor de la Comunidad, porque si lo hablara le costara la vida. Y que oyó este testigo decir que porque un hombre había dicho que había rey, y que había de venir, unos bellacos le dieron de cuchilladas ${ }^{57}$.

\section{Otro parroquiano, Alonso Ortiz,}

vio muchas veces que, estando algunos concilios de los dichos alborotadores y otra gente menuda que con ellos se llegaban, que si algún caballero y hombre de bien -que tuviese buen deseo del servicio del rey y de pacificación de la dicha ciudad- si no hablaba y callaba le levantaban que andaba a oler y escuchar, y si hablaba en favor del bien y pacificación decían que era almagrado (término que se usaba para referirse a los

\footnotetext{
${ }^{56}$ Ibidem, p. 324

${ }^{57}$ Ibidem, p. 327.
} 
traidores). Y luego andaban tras él diciendo que era traidor enalmagrado. Y les convenía huir luego de la ciudad, o le[s] convenía temporizar con ellos, porque no le[s] viniese peligro en su persona y hacienda (...) vio muchas veces [a] algunos de los dichos alborotadores y [a] amigos de ellos andar escuchando y llegándose a donde estaban algunos caballeros y gente de bien a escuchar y sentir lo que hablaban. Y que si hablaban en pacificación de la ciudad, cuando no miraban ni se cataban andaba la grita por la dicha ciudad: " $¡$ Muera fulano, muera fulano! Porque es enalmagrado y habla en paz" (...) aunque hablasen muy secreto en el bien y paz parecía que el diablo se lo hacía saber a los dichos alborotadores ${ }^{58}$ (...) cada y cuando algunos que procuraban el servicio de Su Majestad y la pacificación del pueblo se juntaban a hablar alguna cosa primero miraban a la redonda quién los oía, por temor de las personas malsines que andaban escuchando a ver cuáles eran de su opinión contrarios, y que por esto era sano consejo -y cada uno por tal lo tenía- callar (...) [a] cualquier caballero le mataran y le robaran si lo sintieran fuera de su opinión; y aun sin sentir cosa de ellos los tenían por sospechosos y odiosos, que no se fiaban ${ }^{59}(\ldots)$ traían unos muchachuelos en hábitos de pobres para que anduviesen entre las personas principales para ver lo que decían, o si decían alguna palabra que no fuese útil y provechosa a la dicha Comunidad ${ }^{60}$.

Viéndose sustituidos en sus funciones, el 19 de mayo de 1521 los jurados dieron poder a Nicolás de Párraga para que los representase y, en especial, para que pidiera la anulación de las prerrogativas de los diputados, a quienes no consideraban interlocutores legítimos $^{61}$. Ya en los comienzos de la rebelión algunos jurados habían hecho lo posible por oponerse a los alborotadores. Uno de ellos, Francisco Ramírez de Sosa,

como vio que la maldad en que andaban crecía, importunó [a] algunos jurados para que se juntasen en su Cabildo para ir a favorecer a la justicia. Y que se juntaron los jurados de la dicha ciudad en su Cabildo, y de allí salieron con acuerdo de ir a favorecer al corregidor de la dicha ciudad. Y siendo que iban, oyeron la grita de la gente cómo ya se levantaba la dicha ciudad, y que todavía fueron a casa del dicho corregidor y se ofrecieron a él. Y que luego, dende a poco, este testigo se paró a una ventana que está de cara a la iglesia mayor desde las casas del dicho corregidor, y vio cómo traían al alcalde mayor a trompicones por le librar de la gente. Y luego dijeron que habían prendido al alguacil mayor, Pedro del Castillo, y lo metieron en la iglesia mayor y lo quisieron matar. Y que cargó la gente de la Comunidad hacia la puerta del corregidor, debajo de las ventanas de su casa, y comenzaron a dar voces, y gritos y alaridos, diciendo: “¡Comunidad, Comunidad! ¡Libertad, libertad!”. Y que esto decían los cardadores y zapateros (...) se salieron juntos por una puerta falsa del dicho corregidor, y que después se supo cómo el dicho corregidor fue muy maltratado, y le quitaron la vara y se la tornaron a dar por la Comunidad ${ }^{62}$

Los acontecimientos sobrepasaron el poder de actuación de los jurados. Aunque algunos se resistieron a los alborotadores, no era posible proceder como en

\footnotetext{
${ }^{58}$ Ibidem, pp. 349-350.

${ }^{59}$ Ibidem, p. 354.

${ }^{60}$ Ibidem, pp. 345-348.

${ }^{61}$ F. Martínez Gil, La ciudad inquieta, pp. 153-154.

${ }^{62}$ M.C. Vaquero, El proceso contra, pp. 186-187.
} 
casos precedentes, en los que su labor había sido básica para garantizar el orden. El jurado Juan Sánchez de San Pedro se lamentaba por tal motivo ${ }^{63}$ :

en todas las parroquias de la dicha ciudad hicieron diputados para sus propósitos, sin tomar parecer de ninguno de los jurados que son en esta dicha ciudad, sino antes contra ellos y contra sus oficios (...) en todas las parroquias se hicieron los diputados sin dar parte a jurados ni a otras personas (...) de esta manera hicieron su Congregación, y tenían su escribano y gobernaban la dicha ciudad sin que ningún regidor, ni jurado, ni caballero ni otra persona de buena intención entendiese entre ellos. Y que de allí mandaban hacer fieles ejecutores y otros oficios de la dicha ciudad. Y que lo que ellos mandaban se hacía y ponía por obra. Y que mandaban en sus parroquias que no hiciesen jurados conforme a los privilegios y uso y costumbre, salvo que hubiese diputados como los había y jurados añales, y no de otra manera.

A principios de 1521 las posturas ya se habían radicalizado. Unos deseaban que solo se aceptase la existencia de la Congregación como órgano de gobierno, y otros que el Cabildo de jurados también se mantuviera en vigor, siempre y cuando se reformase en profundidad. Por primera vez desde 1422 el pueblo dudaba sobre lo idóneo de seguir manteniendo a los jurados como sus representantes públicos; a unos jurados que, hundidos en la vorágine de la revuelta, desde 1520 apenas se reunían para no despertar suspicacias que les salieran caro. Los regidores, por su parte, sometidos a la presión de quienes pedían una reforma en el Regimiento para adaptarlo a los intereses del común, dejaron de reunirse en el mes de junio de $1521^{64}$, aunque no pocos insistían en que lo ideal era que el Regimiento no se modificase, sino que prestara más atención a los vecinos, y que cada parroquia tuviera jurados y diputados que de forma conjunta ampararan a la población. Este discurso, con ser el menos radical, no gustaba ni a los regidores ni a la mayoría de los jurados, que afirmaban que la Congregación no tenía un rumbo y actuaba improvisadamente, entre gritos, a golpe de alboroto y sometida al dictamen de los comuneros más apasionados ${ }^{65}$.

Cuando alguna cosa se había de hacer en la dicha ciudad que toca al bien de la paz (...) entraban una gran copetada de alborotadores con otras gentes civiles, con espadas sacadas y escopetas con mechas encendidas (...) en el Ayuntamiento, con mucho escándalo, [a] estorbar la plática y hacer por fuerza lo que ellos querían; y no solamente hablando en la paz, pero en otras cosas que a ellos se les antojaban hacer de hecho. Y que así se hacía en las parroquias.

Las juntas parroquiales debieron ser multitudinarias hasta mediados de 1520. Decenas y decenas de vecinos acudirían a sus parroquias guiados por un sentimiento de expectación y de esperanza, dejándose llevar por ilusiones que con los meses se verían frustradas. Aunque los datos al respecto son pocos, hay un escrito sobre una junta de parroquianos de San Román en plena sublevación que puede compararse con los documentos de las asambleas celebradas en el siglo XV en tal parroquia ${ }^{66}$ (de hecho, las asambleas parroquiales para elegir a los jurados

\footnotetext{
${ }^{63}$ Ibidem, p. 342.

${ }^{64}$ F. Martínez Gil, La ciudad inquieta, p. 306.

${ }^{65}$ M.C. Vaquero, El proceso contra, p. 351.

${ }^{66}$ F. Martínez Gil, La ciudad inquieta, doc. 7, pp. 279-281.
} 
serían la referencia a la hora de organizar la Congregación, si bien ésta fue mucho más lejos). Aunque los vecinos no actuaban en sus juntas desde hacía años eran conscientes de su significación sociopolítica y de su validez a la hora de organizar una nueva forma de gobierno, por lo que examinadas con perspectiva no hay duda que las asambleas de votación de jurados fueron el precedente de las juntas que iban a tener lugar durante la rebelión de los comuneros, en las que por fin pudo oírse la voz de los menores; si bien sólo en principio, hasta que la violencia terminó por corromper su teórico carácter democrático. El testimonio de Alonso Granizo es elocuente ${ }^{67}$ :

estando en la parroquia de Santo Tomé, llamada por los diputados de ella a campana tañida sobre cierto auto que querían hacer, que -según parecía- era contra los dichos alborotadores, y que estando juntos unos decían que se hiciese, que era bien, y otros no, y que sobre esto había gran discordia; y que entre ellos estaban unos siete u ocho, y se tomaron por las manos y dijeron a voces: “iAndad acá, pese a tal! Apártense aquí con nosotros todos los que sois leales y quédense los enalmagrados, y sabremos los que son enalmagrados o no, y aquí haremos lo que hemos de hacer". Y muchos se apartaron con ellos. Y que algunos de ellos iban más por fuerza que por grado, a lo que cree, porque [a] algunos conocía entre ellos que tenían buena voluntad. Y aún este testigo fue con ellos a la una parte de la iglesia, y se fue a su casa, pero que no vio en lo que paró. Pero que así se hacía (...) porque un diputado que se llama Francisco Álvarez se iba fueron tras él y le trajeron diciendo que juraban a Dios que si no volvía que le había de costar la vida, y que de miedo el dicho Francisco Álvarez "volvió".

El 20 de abril de 1520 a la reunión en la parroquia de San Román acudieron hasta 108 hombres, un número altísimo comparado con los que acudían a las asambleas celebradas en el siglo XV. En 1483, por ejemplo, en San Román se celebraron dos reuniones para elegir a un jurado. 148 personas fueron convidadas a la primera y 96 a la segunda, y aun así solo se presentaron 50 y 38 respectivamente $^{68}$, cuando la parroquia de San Román era una de las más pobladas. Los parroquianos, por lo visto, no tenían mucho interés en elegir a sus representantes públicos. Sin embargo, quienes acudieron entonces insólitamente rechazaron a Juan Ruiz, legitimándose en razones que, si bien obligarían a convocar una segunda reunión, no consiguieron impedir que el aspirante al oficio lo acaparara.

$\mathrm{Al}$ contrario que en las juntas parroquiales de las épocas de paz, en rebeliones como la comunera dejó de convidarse a la parroquia; las juntas estaban abiertas a todos los mayores de edad (y tal vez no únicamente a los vecinos hombres, como cuando se elegía a un jurado). Se convocaban a campana tañida y las iglesias se llenaban: al principio gracias al ingobernable fervor revolucionario, y al final, por contra, a causa del miedo a verse en el punto de mira de las críticas. En todo caso, las reuniones serían más multitudinarias que las celebradas a la hora de poner a un jurado. De 15 reuniones que hubo por tal razón entre 1479 y 1486, el número más alto de hombres que se convidaron se dio justamente en la primera junta de San Román, en 1483, a la que se convidaría a 148 parroquianos, de los se presentaron 50. En abril de 1520, como se dijo, acudieron 108.

${ }^{67}$ M.C. Vaquero, El proceso contra, pp. 362-363.

68 AMT, ACJ, DO, “Actas capitulares (1470-11487). Cuentas, cartas, varios”, caja. 23, reunión del 28 de diciembre de 1483 , ff. 198r-s.f. v. 
Es muy interesante observar qué profesiones tenían los sujetos a quienes se convidaba o que acudían tanto a un tipo de juntas como a otras. De los 201 hombres que asistieron o que fueron convidados a las reuniones de la parroquia de San Román en 1483 sólo se conocen los oficios de 75, el 37,31 \%. El conocimiento es mayor en lo relativo a los 108 asistentes a la reunión de 1520, pues hasta 70, el 64,81\%, aparecen identificados con su profesión.

\begin{tabular}{|c|c|c|c|}
\hline \multicolumn{4}{|c|}{ ASISTENTES A LAS ASAMBLEAS DE SAN ROMÁN } \\
\hline \multicolumn{4}{|c|}{ Clérigos y oficiales del gobierno urbano } \\
\hline Oficio & Reuniones de 1483 & Reunión de 1520 & Total \\
\hline Religioso & 3 & 5 & 8 \\
\hline Jurado & 5 & 1 & 6 \\
\hline Regidor & 4 & - & 4 \\
\hline Alguacil & - & 1 & 1 \\
\hline Total & 12 & 7 & 19 \\
\hline \multicolumn{4}{|l|}{ Oficios textiles } \\
\hline Oficio & Reuniones de 1483 & Reunión de 1520 & Total \\
\hline Toquero & 5 & 14 & 19 \\
\hline Tejedor & 2 & 8 & 10 \\
\hline Sastre & - & 7 & 7 \\
\hline Sedero & 3 & - & 3 \\
\hline Bonetero & - & 2 & 2 \\
\hline Colchero & - & 2 & 2 \\
\hline Lanero & 2 & - & 2 \\
\hline Trapero & 2 & - & 2 \\
\hline Agujetero & - & 1 & 1 \\
\hline Botero & - & 1 & 1 \\
\hline Calcetero & - & 1 & 1 \\
\hline Pelaire & - & 1 & 1 \\
\hline Rascador & 1 & - & 1 \\
\hline Torcedor de seda & - & 1 & 1 \\
\hline Total & 15 & 38 & 53 \\
\hline
\end{tabular}




\begin{tabular}{|c|c|c|c|}
\hline \multicolumn{4}{|c|}{ Oficios del metal } \\
\hline Oficio & Reuniones de 1483 & Reunión de 1520 & Total \\
\hline Platero & 14 & 3 & 17 \\
\hline Joyero & 5 & - & 5 \\
\hline Herrero & 1 & - & 1 \\
\hline Ensayador & 1 & - & 1 \\
\hline Total & 21 & 3 & 24 \\
\hline \multicolumn{4}{|c|}{ Oficios relacionados con el comercio } \\
\hline Oficio & Reuniones de 1483 & Reunión de 1520 & Total \\
\hline Mercader & 9 & 1 & 10 \\
\hline Escribano & 3 & 2 & 5 \\
\hline Cambiador & 3 & - & 3 \\
\hline Notario & - & 1 & 1 \\
\hline Corredor & - & 1 & 1 \\
\hline Total & 15 & 5 & 20 \\
\hline \multicolumn{4}{|c|}{ Otros oficios } \\
\hline Oficio & Reuniones de 1483 & Reunión de 1520 & Total \\
\hline Albañil & 1 & 4 & 5 \\
\hline Pintor & 3 & - & 3 \\
\hline Procurador & 3 & - & 3 \\
\hline Barbero & 2 & - & 2 \\
\hline Trabajador & 1 & 1 & 2 \\
\hline Pedrero & - & 2 & 2 \\
\hline Portero & - & 2 & 2 \\
\hline Anzolero & 1 & - & 1 \\
\hline Carnicero & - & 1 & 1 \\
\hline Carpintero & - & 1 & 1 \\
\hline Casero & - & 1 & 1 \\
\hline Criado & - & 1 & 1 \\
\hline
\end{tabular}




\begin{tabular}{|l|c|c|c|}
\hline Despensero & - & 1 & 1 \\
\hline Físico & 1 & - & 1 \\
\hline Médico & - & 1 & 1 \\
\hline Panadero & - & 1 & 1 \\
\hline $\begin{array}{l}\text { Vaquero de } \\
\text { carros }\end{array}$ & - & $\mathbf{1 7}$ & 1 \\
\hline Total & $\mathbf{1 2}$ & $\mathbf{2 9}$ \\
\hline
\end{tabular}

La junta del 20 de abril de 1520 se hizo para que la parroquia de San Román apoderase a sus diputados -Pedro Álvarez de Toledo y Alonso Pérez de la Fuente-, así que la asistencia a la reunión debía ser indiscutible. De lo contrario la autoridad que se les otorgara carecería de fundamento. Todos estaban obligados a participar en la junta, de modo que el no presentarse en ella podía entenderse como exhibición de una falta de compromiso con la sociedad alzada; y de ahí el alto número de asistentes, entre los que, por el contrario, apenas había gobernantes. Solo acudieron un jurado y un alguacil, y hasta cinco eclesiásticos; un dato muy sugerente si tenemos en cuenta que el clero fue en buena medida el causante de la rebelión, gracias a sus discursos incendiarios. Por lo demás, en torno al $80 \%$ de las personas que se reunieron en la iglesia de San Román en 1520 tenían oficios manuales, no como en 1483, cuando los reunidos para el nombramiento de un jurado en su mayoría eran mercaderes o plateros, dos oficios muy de clientes, relacionados con la actividad económica de la élite pechera, integrada por comerciantes, prestamistas y especuladores. Por contra, en 1520 casi todos eran trabajadores del sector textil, toqueros en gran medida, seguidos por los tejedores y los sastres. Es un dato que confirma la idea apuntada por Michael Mollat y Philippe Wolff al referirse a los movimientos sociales de fines de la Edad Media en Europa, cuando dicen que entonces los conflictos se sucedían allí donde la expansión económica había sido más precoz (...) en los focos urbanos de la industria textil $^{69}$. Tiempo atrás, en 1512 , los tejedores de Toledo ya se habían organizado en un cabildo para defender sus intereses; un cabildo que también se podría considerar un antecedente de la Congregación ${ }^{70}$.

En efecto, desde 1510 los artesanos del sector textil eran los más perseverantes en sus críticas al sistema. En el indulto que Carlos I dio a los toledanos terminada la revuelta no hay un solo mercader, lo cual podría explicarse por varias razones: por la ausencia de mercaderes en la ciudad del Tajo en los albores del siglo XVI, lo que es absurdo, ya que los mercaderes eran por entonces un grupo muy dinámico en la urbe; por el desconocimiento que existe sobre la mayoría de los individuos que participaron en la revuelta, cuyas ocupaciones a menudo no son referidas por la documentación; o sencillamente porque el sector mercantil de Toledo no se identificó con las Comunidades, que en esencia fueron una sublevación secundada por los trabajadores textiles, numerosos desde la Baja Edad Media. En este sentido, a la junta de San Román de 1520 solo acudió un mercader, cuando a las celebradas en 1483 lo hacían muchos. Según parece en Toledo (en realidad en todo el centro de Castilla, como ha señalado Joseph Pérez) durante las Comunidades los productores ganaron el partido a

${ }^{69}$ M. Mollar, P. Wolff, Uñas azules, p. 79.

${ }^{70}$ AGS, RGS, 1513-VII (2), Valladolid, 20 de julio de 1513; AMT, ACJ, DO, núm. 95. 
los mercaderes. Pero no solo eso. Los trabajadores más acomodados, los plateros de San Román sin ir más lejos, quedaron en un segundo plano frente a las pretensiones de los trabajadores de menor rango: toqueros, tejedores, sastres y albañiles. Según Fernando Martínez Gil, un buen número de indicios permiten pensar que una de las parroquias más activas y radicales fue la de Santiago del Arrabal, la más habitada y con menor porcentaje de personas acaudaladas ${ }^{71}$.

\section{A MODO DE CONCLUSIÓN}

Las juntas de vecinos para elegir a los representantes de sus parroquias en el gobierno urbano estuvieron celebrándose de forma ininterrumpida entre 1422 y 1520 , y continuarían en el futuro. Aunque siempre fueron manipuladas por los grandes poderes políticos (la Corona y los nobles) y por los pequeños poderes locales (la caballería y los mercaderes), se consideraban un derecho de la comunidad, de los menores, en definitiva, del pueblo llano. La facultad de elegir a quienes tenían que defender a los pecheros ante los omes poderosos era uno de los escasos privilegios que le quedaba al común en el siglo XV, por lo que en los primeros años, al poco de instaurar el Cabildo de jurados, en 1422, el carácter popular de las asambleas para la elección de sus representantes sería notorio. Los domingos, acabada la misa mayor, las parroquias se llenarían de hombres dispuestos a elegir al individuo que iba a defenderlos en caso de tener problemas con las autoridades o con la élite. Sin embargo, como se ha visto, la situación pronto se degradó, por el origen de algunos jurados (conversos), por sus ambiciones personales y por su paulatino abandono de las formas de vida de la población pechera, a la que pertenecían en origen, y de la que se alejaron para conformar un grupo sociopolítico intermedio; una subélite con la que se cebó la opinión pública toledana -famosa por su dureza- siempre que hubo conflictos, dada su incapacidad para ubicarse en una posición social específica. Aun así, el común deseaba poseer un organismo que lo protegiera, como se puso de manifiesto en la rebelión de 1520. Tal organismo, creado entonces bajo el apodo de Congregación, rompió de forma fresca y ambiciosa con las instituciones participativas instauradas (claramente en declive), aun bebiendo de las mismas en su estructura, hasta el punto de convertirse en un órgano equivalente al Cabildo de jurados, aunque con poder ejecutivo y verdaderamente representante de las ambiciones pecheras. Al parecer, fue en épocas de sedición cuando los pecheros manifestaron de forma clara su voluntad de intervenir en política, aunque las tensiones lo frustrasen todo.

\section{BIBLIOGRAFÍA CITADA}

Abellán Pérez, Juan, Ordenanzas sobre el regimiento del cabildo jerezano, "Revista de la Facultad de Geografía de Historia” 4 (1989), pp. 31-40.

Álvarez Bezos, Sabina, Valladolid en la época de los RRCC según el alarde de 1503, Valladolid, Universidad de Valladolid, 1998.

Aranda Pérez, Francisco José, Poder municipal y Cabildo de Jurados en la Edad Moderna (siglos XV al XVII), Toledo, Ayuntamiento de Toledo, 1992.

Aranda Pérez, Francisco José, Privilegio de Juan II por el que se crea, junto al Regimiento, el Cabildo de jurados de Toledo, a imitación del de Sevilla, "Beresit" 4 (1992), pp. 51-55.

${ }^{71}$ F. Martínez Gil, La ciudad inquieta, pp. 213-214. 
Aranda Pérez, Francisco José, Poder municipal, oligarquías urbanas y Cabildo de jurados en Toledo entre los siglos XV y XVI, en Hinojosa Montalvo, José; Pradells Nadal, Jesús (eds.), 1490 en el umbral de la Modernidad. El Mediterráneo europeo y las ciudades en el tránsito de los siglos XV-XVI, Valencia, Generalitat Valenciana, 1994, vol. II, pp. 109-120.

Aranda Pérez, Francisco José, Poder y poderes en la ciudad de Toledo. Gobierno, sociedad y oligarquías en la España moderna, Cuenca, Universidad de Castilla-La Mancha, 1999.

Asenjo González, María, Segovia. La ciudad y su tierra a fines del Medievo, Segovia, Diputación de Segovia, 1986.

Asenjo González, María, Sociedad y vida política en las ciudades de la Corona de Castilla. Reflexión sobre un debate, "Medievalismo" 5 (1995), pp. 89-125.

Asenjo González, María, Espacio y sociedad en la Soria medieval (siglos XII-XV), Soria, Diputación Provincial, 1999.

Asenjo González, María, El ritmo de la comunidad: vivir en la ciudad, las artes y los oficios en la Corona de Castilla, en La vida cotidiana en la Edad Media, Nájera, Instituto de Estudios Riojanos, 1998, pp. 169-200.

Asenjo González, María, El pueblo urbano: el común, "Medievalismo” 13-14 (2004), pp. 181-194.

Benito Ruano, Eloy, La "Sentencia-Estatuto" de Pero Sarmiento contra los conversos toledanos, "Revista de la Universidad de Madrid" 6 (1957), pp. 277-306.

Benito Ruano, Eloy, Memorial del bachiller Marcos García de Mora contra los conversos, "Sefarad" 17 (1957), pp. 314-351.

Benito Ruano, Eloy, Don Pero Sarmiento, repostero mayor de Juan II de Castilla, "Hispania" 27 (1957), pp. 483-504.

Benito Ruano, Eloy, Toledo en el siglo XV. Una historia política, Madrid, CSIC, 1961.

Cantera Burgos, Francisco; León Tello, Pilar, Judaizantes del Arzobispado de Toledo habilitados por la Inquisición en 1495 y 1497, Madrid, Universidad Complutense de Madrid, 1967.

Corral García, Esteban, Las comunidades castellanas y la villa y tierra antigua de Cuéllar, Segovia, Librería Torreón de Rueda, 1981.

Diago Hernando, Máximo, El “común de los pecheros" de Soria en el siglo XV y primera mitad del siglo XVI, "Hispania" 50/174 (1990), pp. 39-91.

García-Jalón de la Lama, Santiago, Los fundamentos jurídicos de la "Sentencia-Estatuto" de Pero Sarmiento, en Actas del I Congreso de Historia de CastillaLa Mancha, Toledo, Junta de Comunidades de Castilla-La Mancha, 1988, tomo VI, pp. 201-204.

Gonzálvez Ruiz, Ramón, Fundamentos doctrinales de la sentencia-estatuto de Toledo contra los conversos, en Inquisición y conversos. III Curso de cultura hispano-judía, Toledo, Universidad de Castilla-La Mancha, 1994, pp. 279-296.

Guerrero Navarrete, Yolanda, Organización y gobierno de Burgos durante el reinado de Enrique IV de Castilla, 1453-1476, Madrid, Universidad Autónoma de Madrid, 1986.

Jara Fuente, José Antonio, Sobre el concejo cerrado. Asamblearismo y participación política en las ciudades castellanas de la Baja Edad Media (conflictos inter o intra-clase), "Studia Historica. Historia medieval" 17 (1999), pp. 113-136.

Jara Fuente, José Antonio, Doble representación y cruce de intereses: las contradicciones inherentes al segmento "élite pechera" (Castilla en el siglo XVI, "Annexes des Cahiers de linguistique et de civilisation hispaniques médiévales" 16 (2004), pp. 297-312. 
Jara Fuente, José Antonio, Posiciones de clase y sistemas de poder: vinculaciones y contradicciones en la construcción del "común de los pecheros" en la Baja Edad Media, en Iglesia Duarte, José Ignacio de la; Martín Rodríguez, José Luis (coords.), Los espacios de poder en la España medieval. XII Semana de Estudios Medievales, Nájera, del 30 de julio al 3 de agosto de 2001, Logroño, Gobierno de La Rioja, 2002, pp. 511-532.

Jular Pérez-Alfaro, Cristina, Nuevas cuestiones sobre el clientelismo medieval. Introducción, "Hispania" 70/235 (2010), pp. 315-324.

López Gómez, Óscar, La sociedad amenazada. Crimen, delincuencia y poder en Toledo a finales del siglo XV, Toledo, Ayuntamiento de Toledo, 2006.

López Gómez, Óscar, Los Reyes Católicos y la pacificación de Toledo, Madrid, Castellum, 2008.

López Gómez, Óscar, Paz social y marginación gubernativa en Toledo. Siglos XI-XV, en Arízaga Bolumboru, Beatriz; Solórzano Telechea, José Ángel (dirs.), La convivencia en las ciudades medievales. Nájera. Encuentros internacionales del Medievo 2007. Actas, Logroño, Gobierno de La Rioja - Universidad de Cantabria, 2008, pp. 429-446.

López Gómez, Óscar, La población marginada de Toledo a finales del siglo XV, en Val Valdivieso, María Isabel del; Martínez Sopena, Pascual (dirs.), Castilla y el mundo feudal. Homenaje al profesor Julio Valdeón, Valladolid, Universidad de Valladolid - Junta de Castilla y León, 2009, vol. III., pp. 369-382.

López Gómez, Óscar, Control político y relaciones de poder en una villa de los marqueses de Villena: Escalona, 1477-1489, en López Gómez, Óscar; Ávila Seoane, Nicolás (dirs.) Escalona, 1083-1554. De la repoblación a los tiempos del Lazarillo, Toledo, Diputación de Toledo - Ayuntamiento de Escalona, 2011, pp. 151-192.

López Villalva, José María, Concejo abierto, regimiento y corregimiento en Guadalajara (1346-1546), "Espacio, tiempo y forma. Historia medieval" 5 (1992), pp. 65-84.

Martín Romera, María de los Ángeles, Nuevas perspectivas para el estudio de las sociedades medievales: el análisis de las redes sociales, "Studia Historica. Historia medieval" 28 (2010), pp. 217-239.

Martínez Gil, Fernando, La ciudad inquieta. Toledo comunera (1520-1522), Toledo, Diputación de Toledo, 1993.

Martínez Gil, Fernando, Furia popular. La participación de las multitudes urbanas en las Comunidades de Castilla, en Martínez Gil, Fernando (coord.), En torno a las Comunidades de Castilla. Actas del Congreso Internacional Poder, conflicto y revuelta en la España de Carlos I, Cuenca, Universidad de Castilla-La Mancha, 2002, pp. 309-364.

Martínez Llorente, Félix, El régimen jurídico de la vecindad medieval y las novedades del ius commune, en Las sociedades urbanas en la España medieval, XXIX Semana de estudios medievales. Estella, 15-19 julio 2002, Pamplona, Gobierno de Navarra, 2003, pp. 51-80.

Martínez Moro, Jesús, Participación en el gobierno de la comunidad de Segovia de los diferentes grupos sociales. La administración de la justicia (13451500), en La ciudad hispánica durante los siglos XIII al XVI. Actas del coloquio celebrado en La Rábida y Sevilla del 14 al 19 de septiembre de 1981, Madrid, Universidad Complutense de Madrid, 1985, vol. II, pp. 701-716.

Molènat, Jean-Pierre, Campagnes et monts de Tolède du XIIe au XVe siècle, Madrid, Casa de Velázquez, 1997.

Mollat, Michael; Wolff, Philippe, Uñas azules, Jacques y Ciompi. Las revoluciones populares en Europa en los siglos XIV y XV, Madrid, Siglo XXI, 1989.

ANUARIO de Estudios Medievales, 42/2, julio-diciembre 2012, pp. 727-753

ISSN 0066-5061, doi:10.3989/aem.2012.42.2.15 
Monsalvo Antón, José María, La sociedad política en los concejos castellanos de la meseta durante la época del regimiento medieval. La distribución social del poder, en Concejos y ciudades en la Edad Media hispánica. II Congreso de Estudios Medievales, Madrid, Universidad Complutense de Madrid, 1990, pp. 357- 413.

Monsalvo Antón, José María, Las ciudades europeas del Medioevo, Madrid, Síntesis, 1997.

Monsalvo Antón, José María, Aspectos de las culturas políticas de los caballeros y los pechos en Salamanca y Ciudad Rodrigo a mediados del siglo XV. Violencias y debates sobre el poder en los concejos, "Annexes des Cahiers de linguistique et de civilisation hispaniques médiévales" 16 (2004), pp. 237-296.

Monsalvo Antón, José María, Ideario sociopolítico y valores estamentales de los pecheros abulenses y salmantinos (ss. XIII-XV), "Hispania" 71/238 (2011), pp. 325-362.

Netanyahu, Benzion, Los orígenes de la Inquisición en la España del siglo XV, Barcelona, Crítica, 1999.

Palencia Herrejón, Juan Ramón, Ciudad y oligarquía de Toledo a fines del Medievo (1422-1522), Madrid, Universidad Complutense de Madrid, 2003.

Parejo Delgado, María José, Grupos urbanos no privilegiados en Úbeda y Baeza durante la baja Edad Media, en Actas del III Coloquio de Historia medieval andaluza. La sociedad medieval andaluza: grupos no privilegiados, Jaén, Diputación de Jaén, 1984, pp. 165-177.

Round, Nicholas G., La rebelión toledana de 1449. Aspectos ideológicos, "Archivum" 17 (1966), pp. 385-446.

Sáez, Carlos, Sepúlveda en la segunda mitad del siglo XV, "Anuario de estudios medievales" 9 (1972), pp. 267-326.

Val Valdivieso, María Isabel del, Ascenso social y lucha por el poder en las ciudades castellanas del siglo XV, "En la España medieval” 17 (1994), pp. 157-184.

Val Valdivieso, María Isabel del, Oligarquía versus común (Consecuencias sociopolíticas del triunfo del regimiento en las ciudades castellanas), "Medievalismo" 4 (1994), pp. 41-58.

Vaquero Serrano, María del Carmen (dir.), El proceso contra Juan Gaitán, Toledo, María del Carmen Vaquero Serrano, 2002.

Walsh, Jonh K. (ed.), El libro de los doce sabios, o Tractado de la nobleza y lealtad (ca. 1237), Madrid, Real Academia Española, 1975.

Fecha de recepción del artículo: septiembre 2011

Fecha de aceptación y versión final: julio 2012 
